\title{
Deepening integration coordinates of the European Assembly
}

\author{
Iulia Andreea Bucur, "Vasile Alecsandri” University of Bacău, Romania
}

\begin{abstract}
The European economic integration is, by its nature, a very complex and multilateral process, representing a wide area for multidisciplinary studies and research. At the same time, in the current context, the European integration acquires new additional valences, reason for which we can say that the significance of issues related to its manifestation is not diminishing but rather increases. Considering the importance and topical of the researched subject, this paper aims to present and highlight the complexity of deepening as a fundamental dimension of European economic integration, and possible consequences resulting from its implementation.
\end{abstract}

\section{Keywords}

deepening, treaties, Customs Union, Internal Market, European Monetary Union, euro

JEL Codes: F02, F15

\section{Introduction}

The complex phenomenon of regional economic integration currently occurs in an impressive and dynamic manner aiming to unify previously distinct economic areas and to intensify economic interdependence between them expressed by increasing flows of goods, services, people, capital and ideas in order to create an open system, which encompasses economic, political, social and other areas.

Same as enlargement, the deepening is a fundamental dimension of the European assembly. The experience has shown that the enlargement has not excluded the deepening and the European Union has succeeded on the two trends proving its capacity to develop both horizontally and vertically.

Deepening process of the European integration (or vertical integration), started in the ' $50 \mathrm{~s}$, involves ${ }^{1}$ two essential considerations: a gradual increase in common objects, which Member States decide to do together by extending common policies and strengthening the supranational character of the Community, through extensive use of majority voting system (instead of based on the existing unanimity in the Council), which are the national interests of each Member State and by strengthening the role of the European Parliament (where European citizens are directly represented).

Over the years, the community requirements and standards have become increasingly rigid with precise rules and criteria for national economic policies of the candidates to align the common European models.

1 Uniunea Europeană: istoric, instituţii, procese decizionale, Seria Micromonografii - Politici Europene, Institutul European din România, 2003, p.7 


\section{Customs Union - first step of deepening European integration}

From the perspective of deepening process of European economic integration, the '50s-' $60 \mathrm{~s}$ period was marked by economic liberalization (establishment of a Customs Union as a prerequisite to achieving the Common Market) and the rules and policies required by unification (Common Agricultural Policy, Common Commercial Policy and Common Transport Policy).

Establishment by the founding members, in 12 years (possibly 15 years if required) of a large market in order to increase the prosperity of Member States of the European Economic Community (EEC) was set as target in the EEC Treaty Article 2 signed at Rome on March 25th, 1957 and became operational from January 1st, 1958. Thus, the EEC began not with a free trade area, but with a Customs Union achieved in 10 years ( 2 years before the time fixed by the EEC Treaty) in July 1, 1968 through the elimination of duties, establishment of common external customs tariff and removal of quantitative restrictions ${ }^{2}$.

In line with the Article 9 (1) of the EEC Treaty, customs union was defined as tariff union representing "all trade in goods and which shall involve the prohibition between the Member States of customs duties on imports and exports and of any charge having effect equivalent, and adopt a common customs tariff in their relations with third countries". Tariff unification was achieved first, by eliminating intra-community customs barriers and align them to the common external customs tariff set at the arithmetic average of duties on January 1st, 1957, in the four areas of the Community Customs (Benelux, France, Italy and West Germany), with some exceptions, particularly for agriculture, and secondly, by lifting other trade barriers and harmonization of national regulations ${ }^{3}$ to an efficient functioning of the Customs Union.

In accordance with the General Agreement on Tariffs and Trade (GATT), Article XXIV, paragraph 8: "The customs union means the replacement of two or more customs territories with a single customs territory in order: (i) customs duties and other restrictive regulations of commerce ... are eliminated for core components of trade union of the territories ... and (ii) ... applied essentially the same duties and other trade regulations by each of the trade union members included in the union territories. ",

EEC Customs Union and the older Benelux Customs Union went far beyond a simple customs union ${ }^{5}$ by including a common agricultural policy to liberalize agricultural trade within the Community, by establishing a common competition policy so that intracommunity trade should not suffer distortions caused by anti-competitive practices, and by the extensive provisions on the harmonization and uniform economic rules and in a somewhat indirect taxation.

EEC Member States have retained many non-tariff trade policy measures, particularly fiscal, technical and physical ones, which are important barriers to mutual trade. Fiscal barriers consist of various forms of indirect taxation (VAT, excise duties in different rates from country to country within the EEC). For example, VAT was introduced in the ' $70 \mathrm{~s}$, but rates vary from country to country within the EEC - from $12 \%$ in Luxembourg to $22 \%$ in Denmark - and only in 1991 was fixed minimum rate 15\% for of all Member States. Technical barriers involve different standards of consumption, country of origin marking of products, banning advertising of imported products, exporting firms must have a representative in the country of export EEC, restriction loans, and more. Physical barriers

\footnotetext{
${ }^{2}$ Nechita V. (1997), Integrarea europeană, Ed. Deşteptarea, Bacău, p.73

3 Ignat I. (2002), Uniunea Europeană. De la Piața Comună la moneda unică, Ed. Economică, București, p.36

${ }^{4} \mathrm{http}: / /$ www.wto.org/english/tratop_e/region_e/regatt_e.htm, webpage accessed on March 10th, 2010

${ }^{5}$ Pelkmans J. (2003), Integrare Europeană. Metodē şi Analiză Economică, Ediţia a II-a, Institutul European din România, Bucureşti, p.8
} 
concern internal customs and internal controls EEC passport. Thus, the 1985 Schengen Agreement is signed between France, Germany and Benelux, agreement to no longer provide internal customs checks and enter into force later in 1995.

Source of attraction for the European countries, Common Market creates a "centripetal force" on their products because of the positive economic and political effects.

\section{Construction of Single Internal Market}

'70s marked slowdown in European economic integration, oil shock and the International Monetary System crisis affecting the development of Europe, while U.S.A. and Japan react more quickly. Amid monetary instability, characterized by large speculative capital movements, in 1978 at Copenhagen European heads of state have decided to create a monetary stability zone as a primary objective of achieving European Monetary System (EMS) established in March 1979 at Paris. EMS is the prove that European leaders have acknowledged the impossibility of creating a single internal market in the absence of a monetary union without a full financial integration.

A new accelerated European integration is achieved by the mid ' 80 s. Thus, in 1985 the Council of Europe adopted the decision to convene an intergovernmental conference to amend the Treaties of Rome. This translates into a single market project, launched by Jacques Delors as President of the European Commission in Brussels. White Paper, established by the Commission, provides the removal, within 7 years, of all obstacles aimed free movement within the EEC and outlines the basic principles of the Single Market project by presenting the measures needed to create it, ultimately leading to the birth of the Single European Act (SEA).

SEA, signed on February 17th, 1986 and ratified by all Member States to July 1st, 1987 is the first significant change to the Treaties of Rome (1957) which established the objective of the single internal market, until December 21st, 1992, by the four freedoms (free movement of goods, free movement of services, free movement of persons and free movement of capital). In addition to these, there is stipulated new common policies implementation by extending the scope of EC competence to assume new responsibilities in areas that were not mentioned by the EEC Treaty: environment, science, technology, research and development, regional policy and achieve economic and social cohesion.

Single Internal Market becomes reality on January 1st, 1993 and its performance should arise from the implementation of three principles: deregulation, aimed at the complete abolition of customs procedures and national regulations that favor domestic producers; harmonization, representing provisions and regulations reform in each of the member countries in order to make them compatible; mutual recognition, when harmonization is not possible, is that, when a state believes that a product has its own rules, so acceptable for domestic consumers, the other states are not allowed to refuse its entry into their territory.

Single Internal Market comprises an area without internal frontiers in which the free movement of goods, persons, services and capital is assured, in other words, a deepening of the common market. It is a market with a mainly social dimension where dynamic competition is stimulated to increase through new means and forms ${ }^{7}$.

(1) Free movement of goods is the foundation of European economic integration and also an area where European construction has made the clearest achievements:

\& Harmonization of VAT and customs duties. Significant non-tariff barriers were removed between 1986-1993, characterized by the existence of protectionist practices, supported by some Treaty provisions, arising from structural problems especially in traditional industries registered member countries, slowing growth and increased

\footnotetext{
${ }^{6}$ Popescu-Bârlan, L. (2009), Construcția Uniunii Europene, Ed. C.H. Beck, Bucureşti, p.62

${ }^{7}$ Cârtiță-Buzoianu C. (2009), Integrarea Europeană: de la aspirația aderării la realitatea integrării comunitare, Ed. Alma Mater, Bacău, p.50
} 
international competition. Goods manufacturers operating in the context of common standards stipulated under the harmonized regulations, accepted by all Member States. Mutual acceptance of testing and certification means that products must be certified only once to be available domestically. Producers, both those inside and outside the EU, can make and sell products with a single technical specification. Shortly, the EU has succeeded in removing barriers to trade in goods that allowed companies in some countries an unfair advantage. For consumers, there are many barriers that may discourage purchases outside their home state, such as inability to use the security or lack of language support. Also, the customs duties may discourage or encourage cross-border shopping.

2 Redefining markets by increasing electronic commerce, consumers being more advantaged by purchasing the goods from suppliers in any EU Member State.

\& Improving consumer protection. Regarding branded goods, where manufacturers seek to control prices to consumers through retailers, there is growing trade in parallel imports. Commercial agents brokers purchase goods to a high standard on low cost markets and then sell them in other Member States where prices controlled by the producers are higher.

Consequently, efforts have focused on establishing a free and effective movement of goods by eliminating obstacles and harmonize national laws.

(2) Free movement of persons. Along with other measures of social harmonization, free movement of persons ensures the social cohesion which is necessary for the existence of a unitary, integrated jointly space. For citizens of EU Member States, freedom of movement includes the right to live, work and move freely. Article 48 in the Treaty of Rome provided free movement of labor principle, "subject to limitations justified on grounds of public order, security and public health" not applicable for the occupations in public administration. In 1968 he was already removed all restrictions on workers and their families stay (in most Member States, however, stay longer than a vacation requires registration). ID cards or passports are required for travel outside a Member State, no visa, work permit or other document was not required. SEA, the Schengen Agreement and the Maastricht Treaty are crucial moments in achieving the "Europe of citizens". But, because of the national disparities still existing, it must continue the harmonization of the laws and strengthening Community competences in order to provide an area without internal borders.

Employers are not allowed to do discriminate on potential employees based on nationality (except some areas such as national security), but there are certain elements that might be considered "barriers" such as recognition, repatriation, and loss of pension rights social security, freedom of movement is not a reality for all Member States (under the transitional arrangements detailed restrictions in the accession treaties that apply for a transitional period from 2 to 7 years). Meanwhile, progress has been greatest in health and safety at work.

(3) Free movement of services. Established in the Treaty of Rome, Article 52 and Article 54 this freedom takes into account two issues: freedom of establishment (the right of an enterprise in a Member State to involve a subsidiary or other unit in any partner country) and freedom to provide (the right to provide services anywhere in the community and regardless of nationality). Achieving the latter requires compliance to a significant extent, the principle of mutual recognition and minimum harmonization. The difficulties in this area arising from insufficient progress in mutual recognition of diplomas and the absence of EU company law.

(4) Free movement of capital, the first of the four freedoms, involves the removal of control over capital transactions, while harmonizing national capital charges to ensure fair competition between countries with low tax and high tax ones. Logical consequence of the free movement of goods, services and people, requires freedom to supply financial services and free movement of capital and trade integration complements and supports. The benefits ${ }^{8}$ derived from this process is a decrease in intermediate costs, diversification, a better

\footnotetext{
${ }^{8}$ Pascariu G.C. (2006), Integrare economică europeană - Curs Jean Monnet, Universitatea „Al.I. Cuza”, Centrul de Studii Europene, Ia $\square$ i, p.36
} 
organization and high possibilities to compete on the international market, increased funding opportunities through better mobilization of European economies.

Consequently, the deepening of European integration has received significant progress in realizing the scope of the idea of achieving the European Single Market aims to achieve a qualitative leap towards the end of 1992 the EEC and also received steps towards a single monetary policy through the creation of the EMS in 1979 and plans to achieve Economic and Monetary Union. Establish an EMS through the European Exchange Rate Mechanism, based on the European Currency Unit ECU, aimed at solving the internal debt of the EEC and preparation of citizens, under psychological aspect, for a single currency.

\section{Economic and Monetary Union (EMU) and the single European currency}

In parallel with developing the Single Market, Economic and Monetary Union (EMU) is intended to complete European economic construction.

Changing European political landscape after the fall of communist regimes in Central and Eastern Europe, led to a structural reform of the EEC towards the creation of political union and EMU. Significant moment in this context is the Maastricht Treaty (signed on February 9th, 1992 and entered into force on November 1st, 1993) marks a new stage in the process of deepening European integration, with the a special status on the grounds that the treaty is essential to amend and strengthen the EU's founding treaties.

There is no generally accepted definition for economic union, even in the Maastricht Treaty the presentation of a definition for the term of economic and monetary union is proving to be difficult. In accordance with the Treaty of Rome, economic and monetary union implies coordinating general economic and social policies in Member States and unification of their domestic markets, thus ensuring not only the free movement of goods but also services, capital and labor, and especially the total and irreversible convertibility of currencies of the Member States and the subsequent release of a single currency.

European monetary unification is an unprecedented experience that can not find equivalent and contributed fundamentally to the EU definition of power as a pole of economic and political map of the world. The Maastricht Treaty states as EU major objective launching and implementation of EMU in three stages. The first phase (July 1st, 1990 to December 31st, 1993) has as main objectives: liberalization of capital movements, completing the single market debut amid economic convergence process multilateral surveillance of economic policies of states. The second stage (January 1st, 1994 to December 31st, 1996) covered the following objectives: creating the European Monetary Institute with the mission to strengthen monetary cooperation between central banks and monetary policy coordination to ensure price stability; outline the convergence criteria. EMU was an important step in achieving economic union, and therefore towards deepening European integration. Simultaneously with the enlargement to Central and Eastern Europe, started the third stage of monetary union, replacing the national currencies of Member States with the euro, the irrevocable fixing of exchange rates and start of operation of the European System of Central Banks (ESCB) consists of the European Central Bank (ECB) and national central banks.

Although the idea of a single currency has existed since 1968, with the introduction of the Customs Union and the EMS in 1979 and signing up in 1986, the SEA, which enshrined the four freedoms of movement are important steps in achieving monetary unification, only in 1994 were initiated preparations towards the euro, first replacing national currencies as the currency of account since 1999 and then enter into circulation in 2002.

Preparations for EU accession, in accordance with the Copenhagen criteria, establish practical rules for monetary unification. Transition to EMU membership implies two key issues: participation of Member States to Exchange Rate Mechanism II and demonstrate a high level of sustainable convergence performance by them, in order to adopt euro.

Introduction of the euro has some advantages and disadvantages, reason for which we point some main EMU effects on the euro area countries. 
Effects on the competitiveness of Member States. Completing the Single Market and the euro participating economies and competitiveness concerns of increased investment in human capital, thus helping to increase production, income, employment and inflation reduction. Increased market transparency and price is likely boost their alignment and to boost the competitive environment. As regards European companies exporting single currency leads to increased competition in the single European market and also some operational costs are reduced by the fact that some companies are able to conduct international transactions in euro more than was capable in national currency.

Effects on EU external relations. a) EMU generates an intense development and growth balance between the main actors in the international financial system that Euro zone, the U.S.A. and Japan, contributing to increased individual responsibility to ensure a stable global environment, Japanese and American companies will benefit from removing barriers currency single European market and consolidation monetary stability in the euro area, the world economy will become more symmetric; b) EMU, with its economic power, is an anchor of stability for the neighboring countries by linking their national currencies for the euro, these countries can obtain the benefits of price stability and from policies aimed at stability in the euro area; c) EMU promotes stability and boost economic growth in the euro area, this having a positive effect on trade and investment relations with other countries; d) EMU offers new opportunities for financial investors around the world to diversify investments and to reduce risks.

Effects on currency stability. The introduction of the euro contributes to creating stable monetary relations and the elimination of currency risk when trading in the euro area, which, especially in export-oriented countries, leading to the possibility of creating new jobs. Costs transactions are reduced, because only this includes costs related to currency risk.

Effects on employment. Adopting the single currency is a base for employment, resulting in a reduction in interest rates, leading to encouraging investment and growth - two essential conditions for creating new jobs.

Effects on consumers. Benefits for consumers are: reducing costs for travel in foreign countries, remittances to other countries easier and less costly, greater transparency in costs and increasing competition, both resulting in lower prices, eliminate exchange rate risk countries euro area, reducing interest rates while cutting costs relative to loans, the safety of purchasing power due to inflation reduction, sustainable economic growth leading to job security.

Effects on transport. Euro has generally positive effect on transport between EU Member States by reducing intra stimulating conversion costs per transaction, which creates an increased demand for transport services.

Effects on interest rates. A reduction of inflation through monetary policy pursued by the ECB as well as rising stock market liquidity as space and interest rates tends to decrease.

Effects on growth. Stimulate structural reforms and encourage economic growth stemming from lower transaction costs of foreign exchange reduced or even eliminated the price transparency.

Effects on the sovereignty of Member States. The only aspect of national sovereignty within the meaning of national power of autonomous action in this area directly affected by EMU is monetary policy.

Effects on national economic policy. EMU Member States remain responsible for national economic policy, although no longer entitled to have an independent monetary policy. Also increases near the EMU economies in the euro area, this needs a supervision and coordination of their economic policies.

Effects on taxes. The single currency itself is not responsible for the overall increase in the level of taxation of citizens, but can cause changes in national tax system. While the single market with a single currency require harmonization of tax systems, significant differences between the tax rates may cause economic distortions. 
The creation of EMU has sought to achieve at least two goals. In the first instance, the Monetary Union wants to provide a catalyst for further political integration of Western Europe, and in the second, to achieve more dynamic growth and a higher use of labor.

\section{Conclusions}

The European Union is, at present, the most advanced model of regional integration. Continuity is the essence of European construction, the principle set out in the Treaty of Rome in 1957 by its founders "an ever closer Union among the people of Europe". Permanent and continuous nature of European construction, throughout its evolution, is offered by the two dimensions: enlargement by the integration of new Member States and deepening or qualitative integration, as essential objectives for its continued development and strengthening. Deepening integration resulted in generating more interest as the states outside the EC/EU accession to, and hence the security and a greater appetite of the EC/EU enlargement.

European experience of economic integration is unprecedented in terms of deepening economic integration through dynamic economic development, achieving the largest single internal market in the world, creating the euro area, achievements of European economic integration process prints a single character. EU's ability to function effectively in response to citizens concerns can and should be further improved, but this objective can be achieved by stopping the expansion and especially the deepening. Therefore, the EU can continue to enlarge and deepen through a process of gradual and carefully managed accession, along with internal reforms of its institutions and policies to avoid the so-called "differentiated integration" or an Europe "with more speed".

European assembly is an expression of successful idea - the idea of united Europe and of $a$ will - the political will of most Western European countries, creating one of the most important trading powers and providing some of the highest civilization and living conditions.

\section{Bibliography}

1. Cârtiță-Buzoianu, C. (2009), Integrarea Europeană: de la aspirația aderării la realitatea integrării comunitare, Ed. Alma Mater, Bacău

2. Ignat, I. (2002), Uniunea Europeană. De la Piața Comună la moneda unică, Ed. Economică, Bucureşti

3. Nechita, V. (1997), Integrarea europeană, Ed. Deşteptarea, Bacău

4. Pascariu, G.C. (2006), Integrare economică europeană - Curs Jean Monnet, Universitatea „Al.I. Cuza”, Centrul de Studii Europene, Ia $\square$ i

5. Pelkmans, J. (2003), Integrare Europeană. Metode şi Analiză Economică, Ediția a II-a, Institutul European din România, Bucureşti

6. Popescu-Bârlan, L. (2009), Construcția Uniunii Europene, Ed. C.H. Beck, Bucureşti

7. Uniunea Europeană: istoric, instituții, procese decizionale, Seria Micromonografii Politici Europene, Institutul European din România, 2003

8. http://eur-lex.europa.eu/

9. http://www.wto.org/ 